\title{
Esportividade, melancolia, nacionalismo e deficiência: a cobertura fotográfica dos jogos paralímpicos pelas lentes da Folha de São Paulo (1992 - 2016)
}

\author{
Silvan Menezes Dos Santos' \\ Antonio Luis Fermino ${ }^{2}$ \\ André Marsiglia Quaranta ${ }^{3}$ \\ Doralice Lange de Souza ${ }^{4}$
}

\section{RESUMO}

Esta pesquisa teve como objetivo caracterizar a representação imagética do esporte e dos atletas paraolímpicos na cobertura fotográfica do jornal Folha de São Paulo durante a realização dos Jogos Paralímpicos no período de 1992 a 2016. O estudo foi de cunho quanti-qualitativo, descritivo e exploratório e se baseou na teoria do enquadramento. Houve um aumento no número de fotografias publicadas no decorrer dos anos, sendo que algumas das características principais das fotos são: esportividade dos atletas; melancolia associada à deficiência; promoção de nacionalismo; e espetacularização do grotesco e do ciborgue. O caráter polissêmico das representações propagadas nas fotografias revela algumas das complexidades envolvidas nas formas de se conceber atletas com deficiência e a necessidade de se melhor qualificar a mídia para futuras coberturas do esporte paralímpico.

Palavras-chave: Jogos paralímpicos. Semiótica. Enquadramento. Mídia esportiva

1 Doutor em Educação Física pela UFPR. Professor da Universidade Federal do Mato Grosso do Sul, Brasil. E-mail: bammenezes90@gmail.com

2 Doutorando no Programa de Pós-Graduação em Educação Física na Universidade Federal do Paraná (UFPR). Curitiba/Paraná, Brasil. E-mail: antonioluisf@gmail.com

3 Doutorando no Programa de Pós-Graduação em Educação Física na Universidade Federal do Paraná (UFPR). Curitiba/Paraná, Brasil. E-mail: andrequaranta@gmail.com

4 Doutora em Educação. Professora no Departamento e Programa de Pós-Graduação em Eduação Fìsica na Universidade Federal do Paraná (UFPR). Curitiba/Paraná, Brasil. E-mail: desouzdo@post.harvard.edu

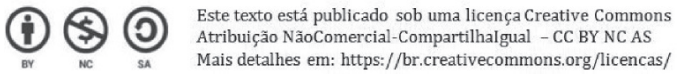


Sportivity, melancolia, nationalism and disability: the photographic coverage of the paralympic games through the lenses of folha de são paulo (1992 - 2016)

\begin{abstract}
This study aimed to characterize the image representation of sport and Paralympic athletes in the photographic coverage of the "Folha de São Paulo" newspaper during the Paralympic Games from 1992 to 2016. The study was quanti-qualitative, descriptive and exploratory and was based on the framework theory. There has been an increase in the number of photographs published over the years, and some of the main characteristics of the photos are: athletes' sportsmanship; melancholy associated with the deficiency; promotion of nationalism; and spectacularization of the grotesque, and the cyborg. The polysemous character of the representations propagated in the photographs reveals some of the complexities involved in conceiving disabled athletes and the need to better qualify the media for future coverage of Paralympic sport.
\end{abstract}

Keywords: Paralympic games. Semiotics. Framework. Media sports

La cobertura fotográfica de los juegos paralímpicos por las lentes de la folha de são paulo (1992 - 2016)

\title{
RESUMÉN
}

Esta investigación tuvo como objetivo caracterizar la representación imagética del deporte y de los atletas paraolímpicos en la cobertura fotográfica del diario Folha de São Paulo durante la realización de los Juegos Paralímpicos en el período de 1992 a 2016. El estudio fue de cuño cuantitativo cualitativo, descriptivo y exploratorio y, se basó en la teoría del encuadramiento. Se ha producido un aumento en el número de fotografías publicadas a lo largo de los años, siendo que algunas de las características principales de las fotos son: deportividad de los atletas; melancolía asociada a la discapacidad; promoción del nacionalismo; y la espectacularización del grotesco y del ciborgue. El carácter polisémico de las representaciones propagadas en las fotografías revela algunas de las complejidades involucradas en las formas de concebir atletas con discapacidad y la necesidad de mejor calificar los medios para futuras coberturas del deporte paralímpico.

Palabras clave: Juegos paralímpicos. Semiótica. Directrices. Medios deportivos 


\section{INTRODUÇÃO}

Vivemos em uma sociedade do espetáculo na qual, conforme aponta Debord (1997), as relações sociais são mediadas por imagens. Ou seja, na esfera social somos compreendidos e compreendemos os outros por uma imagem construída e reproduzida sobre nós, por nós e sobre os outros. Os meios de comunicação de massa são, neste contexto, mediadores culturais hegemônicos dos nossos modos de compreender e de sermos compreendidos no mundo (MARTíN-BARBERO, 2004, 2009). Isto vale para as compreensões de nação, povo, raça, etnia, gênero, bem como de outras dimensões da vida, tais como esporte, deficiência, pessoas com deficiência, uma vez que estes são fenômenos, manifestações e agentes presentes na sociedade contemporânea.

Os Jogos Paralímpicos (JP), um dos maiores megaeventos esportivos do planeta, se constituem em uma importante manifestação social e midiática das pessoas com deficiência. Portanto, este é um fenômeno social fortemente influenciado pela mediação que os meios de comunicação de massa fazem da imagem delas. Isto posto, coadunando com o provérbio atribuído ao filósofo chinês Confúcio, de que uma imagem vale mais do que mil palavras, o objetivo deste trabalho foi o de compreender a representação imagética do esporte e de atletas paraolímpicos na cobertura fotográfica do jornal Folha de São Paulo ${ }^{5}$ (FSP) durante a realização dos JP no período de 1992 a $2016^{6}$. Buscamos explorar, mais especificamente, discursos não verbais sobre os atletas e sobre o esporte paraolímpico que se fizeram presentes na cobertura fotojornalística da FSP durante os Jogos Paralímpicos de 1992 a 2016.

Existem, no cenário internacional e nacional, alguns estudos que vem discutindo as relações entre a mídia e esporte paraolímpico. Mais especificamente sobre fotografias e imagens veiculadas a respeito do esporte e dos atletas paraolímpicos, existem algumas investigações pontuais realizadas por Bruce (2014) e Pappous, Marcellini e De Léséleuc (2011) e Figueiredo (2014). Diante deste quadro, o nosso estudo visa investigar como um dos principais veículos de mídia do país, a FSP, apresentou fotograficamente a imagem do esporte e dos atletas paraolímpicos durante as últimas sete edições dos JP. Definimos 1992 como o ponto de partida a ser investigado por ter sido em Barcelona, neste ano, a primeira edição dos JP após a fundação do Comitê Paralímpico Internacional (IPC - International Paralympic Committee) em 1989. Este fato, que demarca o início da burocratização institucional do esporte paraolímpico, impulsionou o processo de midiatização e de mercadorização do mesmo como fenômeno social contemporâneo.

Destacamos a importância de se estudar o enquadramento jornalístico do esporte e dos atletas paralímpicos porque, conforme reforçam Maika e Danylchuk (2016), a mídia

5 Considerado um dos principais jornais do país com 96 anos de existência. Possui edição online e está presente também na cobertura de diferentes megaeventos esportivos, sendo este material uma grande fonte de pesquisas para o campo da Educação Física.

61992 - Barcelona; 1996 - Atlanta; 2000 - Sydney; 2004 - Atenas; 2008 - Pequim; 2012 - Londres; 2016 - Rio de Janeiro. 
seleciona e omite determinados tipos de informações encaixando-as em padrões que tendem a reproduzir o status quo e a "naturalizar" determinados entendimentos que se tem da realidade. Também como reiteram estes autores, as histórias que são por ela reproduzidas podem influenciar tanto positivamente quanto negativamente as representações sociais que normalmente se tem acerca das pessoas com deficiência.

\section{Percursos e estratégias metodológicas}

Realizamos uma pesquisa de cunho quanti-qualitativo, descritivo e exploratório e utilizamos como base teórica-metodológica a teoria do enquadramento. Este referencial permite que se identifique os diferentes recortes e elementos selecionados, excluídos e enfatizados nas veiculações da comunicação midiática sobre os fenômenos sociais (MENDONÇA; SIMÕES, 2012; ROTHBERG, 2010). Tomando como base Maika e Danylchuk (2016), que adotaram esta mesma perspectiva para verificar o teor das notícias de dois jornais canadenses a respeito da cobertura dos Jogos Paralímpicos de Londres em 2012, nos utilizamos da mesma abordagem para verificar o recorte fotográfico que foi feito da imagem dos atletas paraolímpicos por parte da FSP. Levamos em consideração o que foi possivelmente excluído do recorte fotográfico feito sobre os atletas. Procuramos caracterizar aquilo que foi escolhido mostrar e o que foi enfatizado pela FSP nas imagens dos atletas paraolímpicos. Partimos de enquadramentos imagéticos consolidados ao longo das publicações do jornal impresso FSP. Ou seja, a teoria do enquadramento nos auxiliou a perceber os enfoques dado pelo referido jornal ao longo de sete edições dos JP. Com relação à semiótica da cultura, esta, por sua vez, nos possibilitou uma descrição da linguagem imagética que foi produzida sobre o esporte paraolímpico e seus participantes.

Também utilizamos como suporte de análise a semiótica da cultura, que visa "conhecer as linguagens produzidas pelos diferentes sistemas culturais e como elas produzem significações" (MACHADO, 2007, p. 19). Mobilizamos esta perspectiva analítica com o intuito de compreender como a interação entre uma mídia de massa (a FSP) e o esporte podem ter resultado em diferentes dinâmicas de significação sobre o movimento paraolímpico, sobre o esporte para pessoas com deficiência e sobre as próprias pessoas com deficiência, considerando ambos (mídia e esporte) como espaços culturais constituídos por valores, códigos e simbologias próprias.

Recolhemos as versões impressas do jornal durante o período de realização das sete últimas edições dos JP, incluindo o dia anterior à abertura e o dia posterior ao encerramento das mesmas. As edições do jornal foram acessadas na Biblioteca Pública do Estado do Paraná que possui acervo das versões impressas da FSP. As imagens relacionadas ao megaevento foram catalogadas e digitalizadas gerando um total de 170 fotografias, porém consideramos para o corpus de análise 146 delas. Descartamos 24 imagens por retratarem personalidades da gestão burocrática do esporte paraolímpico, equipamentos esportivos da infraestrutura dos Jogos, ou porque estavam contidas em peças publicitárias. As fotos recolhidas continham quatro características importantes, que foram transformadas em categorias para fins de organização dos dados e análises. 
Utilizamos da técnica de análise do enquadramento, conforme sugerida por Rothberg (2010), para identificar o que foi selecionado, excluído e enfatizado no recorte fotográfico veiculado pela FSP e assim organizar os dados nas quatro categorias. Isso nos permitiu, por exemplo, que categorizássemos as imagens entre as que enquadravam e enfocavam elementos esportivos, as que apresentavam um quadro não esportivo abordando outros elementos subliminares em torno da pessoa com deficiência, as que colocavam em evidência as deficiências dos atletas e as tecnologias assistivas utilizadas por eles, e/ou as que apresentavam símbolos sugestivos dos ideais de nacionalismo de maneira circundante ou diretamente associada ao esporte paraolímpico. Assim, nomeamos as categorias da seguinte forma:

1. A esportividade paraolímpica - Inclui imagens compostas por atletas em competição, nos campos de disputa e utilizando indumentária característica de suas modalidades. Também abrange imagens que apresentam atletas em oposição a adversários, assim como fotos que mostram símbolos do movimento paraolímpico, tal como os Agitos do Comitê Paralímpico Internacional, e/ou as marcas das edições que foram disputadas (ex. Rio/2016, Londres/2012, etc.);

2. A melancolia da deficiência - Abrange imagens que retratam os atletas com deficiência em momentos de solidão e com expressões faciais de tristeza, de dor ou com um sorriso de aparente pesar. Aborda também fotos escuras e que enquadram a sombra dos atletas paraolímpicos;

3. O nacionalismo no esporte paraolímpico - Compreende fotografias que apresentam personalidades esportivas que trazem consigo um potencial simbólico de representação das nações. Abarca também símbolos de destaque do megaevento como cerimônias de abertura e encerramento, que simbolizam a união entre as nações. Além disto, abrange imagens que ressaltam a bandeira e as cores do Brasil e onde a identificação da nacionalidade é mais enfatizada do que a performance esportiva do atleta;

4. Espetacularização do grotesco e do ciborgue - Abrange imagens que enfocam as deficiências, próteses e/ou as cadeiras de rodas dos atletas paraolímpicos. Inclui também fotografias que evidenciam alguns comprometimentos severos de atletas e/ou a conexão corporal dos mesmos com os aparatos tecnológicos.

Após organizar e definir a categorização dos dados a partir dos objetos significantes expostos, excluídos e/ou enfatizados pelo enquadramento fotográfico da FSP, utilizamos da perspectiva da semiótica da cultura para explorar diferentes significados passíveis de serem atribuídos à representação imagética do esporte e dos atletas paraolímpicos. Deste modo, exploramos a diversidade da significância desta manifestação esportiva no contexto da cultura midiática conforme indícios outrora apontados pela literatura científica da área que tem se debruçado sobre a temática.

Faz-se importante ressaltar, no entanto, que ao mesmo tempo em que estas categorias emergiram dos dados, elas dialogam, direta ou indiretamente com resultados de outros estudos (ex. BRUCE, 2014; MAIKA; DANYLCHUK, 2016; PAPPOUS, MARCELLINI E DE LÉSÉLEUC, 2011; FIGUEIREDO, 2014) e com trabalhos técnicos produzidos por intelectuais 
dezembro/2018

direcionado aos jornalistas, entre eles, os guias de orientações à mídia sobre como veicular as imagens de atletas com deficiência que surgiram a partir de 2012 (BRITISH PARALYMPIC ASSOCIATION, 2012; INTERNATIONAL PARALYMPIC COMMITTEE, 2014; PAPPOUS; SOUZA, 2016).

\section{Apresentação e discussão dos dados}

Apresentamos na tabela 1 a distribuição quantitativa e percentual das categorias de acordo com o ano de realização dos JP. Ressaltamos que, por considerarmos os diversos elementos sígnicos que compunham as imagens e também os diferentes enquadramentos fotográficos, as categorias de análise não são auto excludentes. Ou seja, as fotografias foram catalogadas em mais de uma categoria.

Tabela 1: Distribuição quantitativa e percentual das categorias empíricas por ano de realização dos JP

\begin{tabular}{l|c|c|c|c|c|c|c|c|c}
\hline \multicolumn{2}{c|}{ CATEGORIA } & \multicolumn{2}{c|}{$\begin{array}{c}\text { ESPORTIVIDADE } \\
\text { PARAOLÍMPICA }\end{array}$} & \multicolumn{2}{c|}{$\begin{array}{c}\text { MELANCOLIA DA } \\
\text { DEFICIÊNCIA }\end{array}$} & \multicolumn{2}{c|}{ NACIONALISMO } & \multicolumn{2}{c}{$\begin{array}{c}\text { DO GROTESCO AO } \\
\text { CIBORGUE }\end{array}$} \\
\hline ANO & $\begin{array}{c}\text { No DE } \\
\text { IMAGENS }\end{array}$ & $\mathrm{N}$ & $\%$ & $\mathrm{~N}$ & $\%$ & $\mathrm{~N}$ & $\%$ & $\mathrm{~N}$ & $\%$ \\
\hline 1992 & 2 & 2 & 2,82 & 0 & 0,00 & 0 & 0,00 & 0 & 0,00 \\
\hline 1996 & 7 & 1 & 1,41 & 2 & 11,11 & 5 & 10,42 & 0 & 0,00 \\
\hline 2000 & 16 & 7 & 9,86 & 4 & 22,22 & 4 & 8,33 & 2 & 4,65 \\
\hline 2004 & 19 & 11 & 15,49 & 1 & 5,56 & 5 & 10,42 & 3 & 6,98 \\
\hline 2008 & 24 & 10 & 14,08 & 3 & 16,67 & 8 & 16,67 & 5 & 11,63 \\
\hline 2012 & 19 & 8 & 11,27 & 0 & 0,00 & 3 & 6,25 & 9 & 20,93 \\
\hline 2016 & 83 & 32 & 45,07 & 8 & 44,44 & 23 & 47,92 & 24 & 55,81 \\
\hline TOTAL & 170 & $\mathbf{7 1}$ & 100,00 & 18 & 100,00 & $\mathbf{4 8}$ & $\mathbf{1 0 0 , 0 0}$ & $\mathbf{4 3}$ & 100,00 \\
\hline
\end{tabular}

Fonte: produção dos autores

O quadro acima mostra que houve um aumento no número de fotografias publicadas ao longo dos anos, de duas imagens na edição de 1992 para 83 imagens em 2016. Paralelamente a isto, com algumas pequenas variações, houve também um aumento expressivo de fotos que se encaixaram nas diferentes categorias. Durante os Jogos Rio 2016, houve um salto numérico significativo no número de fotos em geral, que por sua vez, pode ser atribuído ao fato do evento ter sido sediado "em casa".

\section{A Esportividade Paraolímpica}

As fotografias que enquadraram o desempenho esportivo dos atletas são a principal expressão desta categoria: a explosão durante a largada, o desenvolvimento da prova, a superação do(s) adversário(s), a vitória e o coroamento no pódio, o enfoque na técnica e na performance esportiva. Seguem abaixo alguns exemplos. 


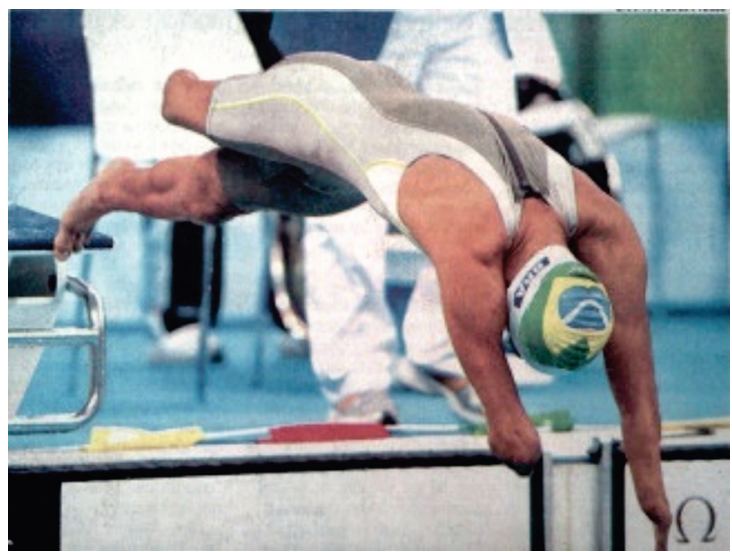

Figura 1: FSP (08/09/2008)

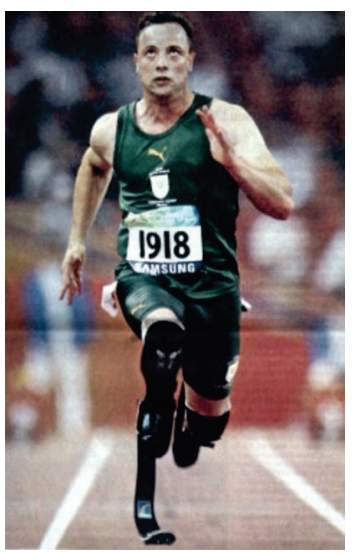

Figura 2: FSP (09/09/08)

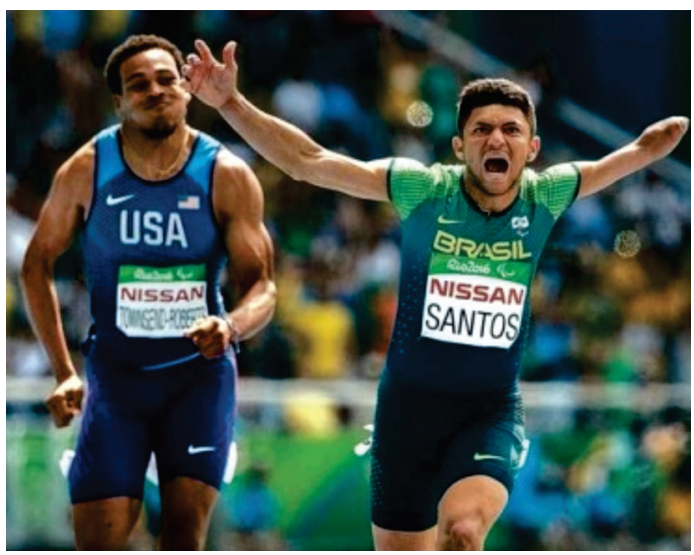

Figura 3: FSP

Cabe ressaltar que as figuras acima retratam os corpos dos atletas paraolímpicos em seu espaço de desempenho esportivo sem esconder as deficiências dos mesmos e sem enfatizá-las. O tipo de enquadramento das fotos citadas está de acordo com as recomendações dos guias de orientações à mídia sobre como veicular as imagens de atletas com deficiência. De acordo com os guias de orientações à mídia, este tipo de enquadramento é positivo, pois mostra a esportividade e competitividade dos atletas paraolímpicos, bem como determinadas potencialidades das pessoas com deficiência. Autores como Brittain e Beacom (2016), porém, lembram que existe o risco de que a partir de signos como estes, outras pessoas com deficiência passem a ser medidas a partir de parâmetros estabelecidos pela performance dos atletas tal como mostrados na mídia. Aqueles que não conseguem 
se equiparar, podem ser negativamente julgados por não tentarem ou não conseguirem o êxito necessário. Faz-se importante ressaltar, no entanto, que este tipo de representação ocorre também no âmbito do esporte olímpico e que todos nós - pessoas com e sem deficiências - corremos o risco de sofrermos este tipo de comparação.

As figuras 4 e 5 são outro tipo de manifestação da categoria aqui analisada. Elas mostram apertos de mãos / cumprimentos entre adversários. Este tipo de enquadramento fotográfico reforça imageticamente a ideologia do fair play (jogo limpo), um dos principais códigos institucionais do esporte.

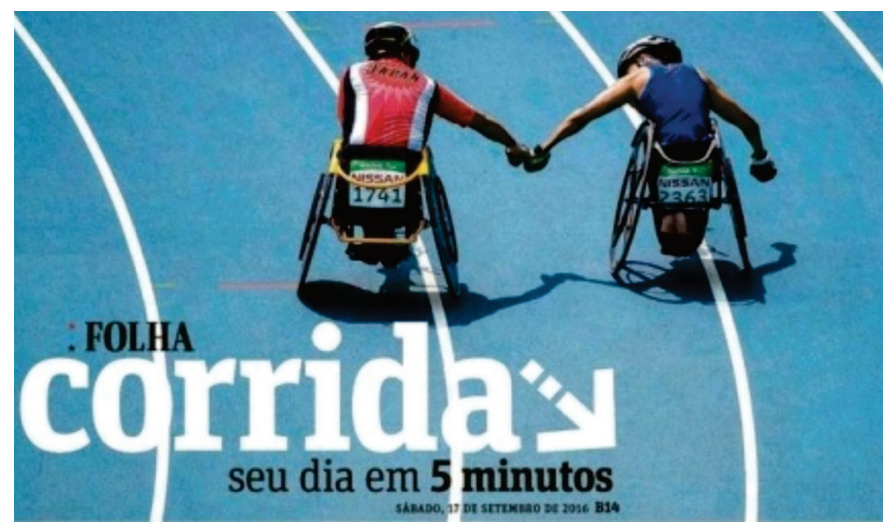

Figura 4: FSP (17/09/2016)

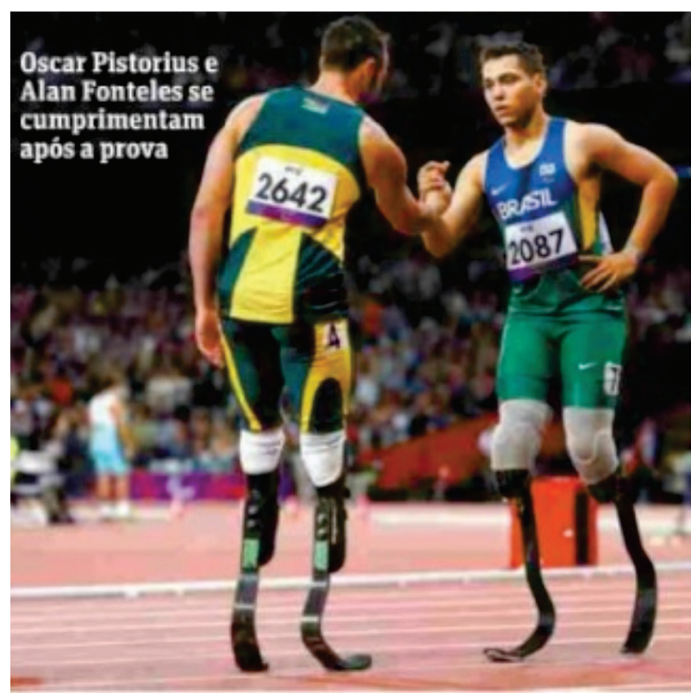

Figura 5: FSP (03/09/2012) 
A representação sígnica e o enquadramento fotográfico das figuras 4 e 5 ajudam também a sustentar o ideal de cordialidade e de suposta pureza normalmente associada ao contexto paraolímpico, que por sua vez, tem sido comumente percebido como um espaço de circulação unívoca de "bons moços" (GONÇALVES; ALBINO; VAZ, 2009). A preferência por este tipo de enquadramento fotográfico deixa de fora imagens que denotam conflito e delitos que ocorrem no esporte paraolímpico, tal como no esporte olímpico. Em relação a isto, um estudo de Howe (2008) verificou que durante os Jogos Paralímpicos de 2004, houve uma recomendação para que a mídia não produzisse notícias sobre polêmicas envolvendo casos de doping e questões relacionadas à classificação funcional dos atletas.

A figura 6 abaixo exemplifica a exploração de imagens que conferem um simulacro sobre-humano ao espetáculo esportivo paraolímpico. A condição supostamente sobre-humana dos atletas paraolímpicos - circunstância esta que apresenta a superação de limites no esporte como algo que está além das condições humanas comuns de existência - tem sido reincidente na cobertura midiática do esporte paraolímpico.

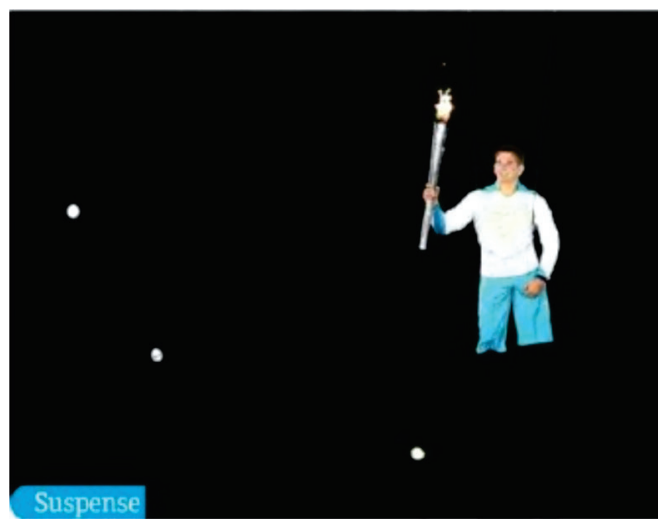

Figura 6: FSP (30/08/2012)

A figura 6 é uma veiculação fotográfica da FSP que exemplifica uma narrativa comum na mídia sobre o esporte paraolímpico denominada de supercrip ${ }^{7}$. A recorrência desta narrativa pode levar o universo semiótico e esportivo paraolímpico a ser percebido como algo fora do normal, surpreendente, impensável. Esta é uma configuração semiótica advinda da conjunção da cultura midiática com a cultura esportiva, sendo que a primeira utiliza a linguagem do espetáculo e do espetacular e a segunda tem como seus códigos hegemônicos a superação de obstáculos e a busca por recordes.

7 A abordagem midiática do esporte paraolímpico denominada de supercrip reforça a ideia de que o atleta é uma espécie de super-herói que, "apesar" de suas deficiências, com o seu próprio esforço, dedicação e vontade, consegue superar obstáculos e vencer (HARDIN; HARDIN, 2004; SILVA; HOWE, 2012). 
Outro elemento identificado como representação de esportividade é a presença de atletas do movimento olímpico e do esporte convencional junto ao esporte adaptado e paraolímpico, conforme exemplificado nas figuras 7 e 8.

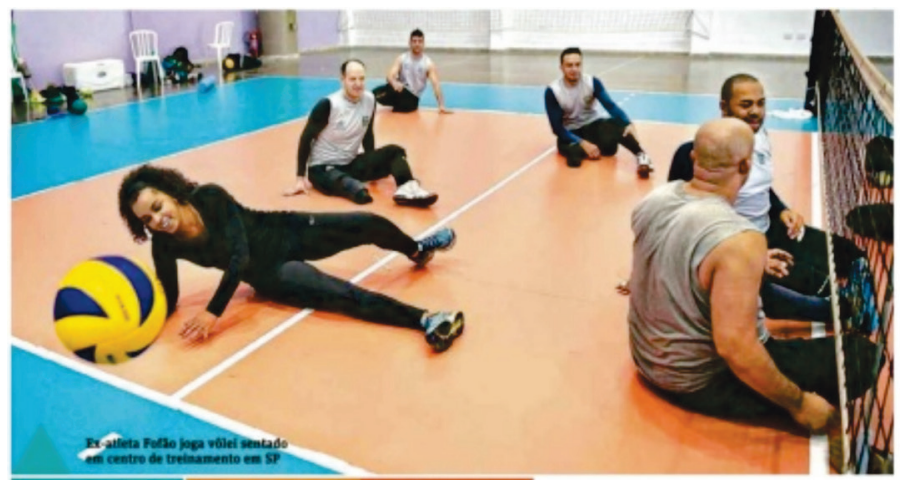

Figura 7: FSP (06/09/2016)

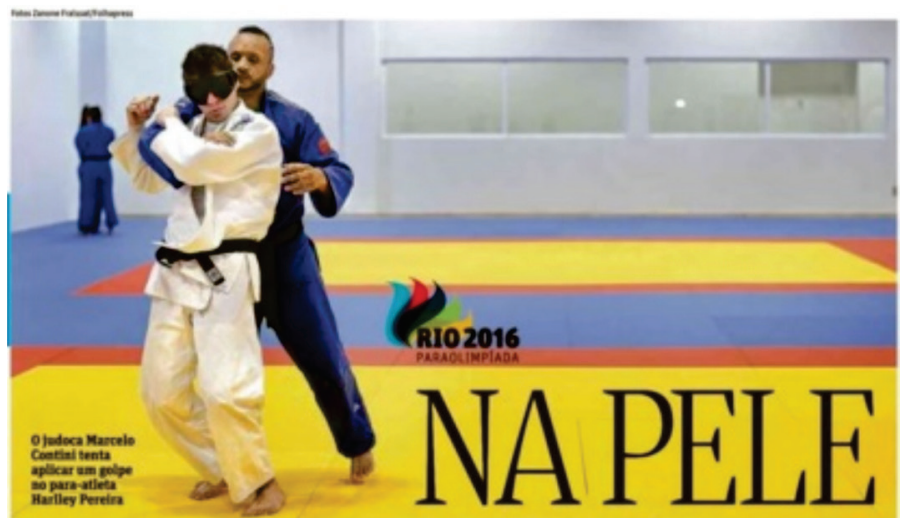

Figura 8: FSP (06/09/2016)

A figura 7 enquadra o treinamento da equipe paraolímpica de vôlei sentado com a participação da atleta do vôlei tradicional, Fofão. A figura 8 mostra um atleta com deficiência visual do judô com um atleta sem deficiência. Estes enquadramentos fotojornalísticos apresentam elementos indicativos que sugerem, por sua vez, a excelência esportiva de modalidades paraolímpicas, pois selecionam e enfatizam a atuação de atletas com deficiência em par de igualdade com atletas de alto rendimento sem deficiência. Tal construção imagética coaduna com o discurso e com a ideia de que o esporte paraolímpico se configura como uma manifestação esportiva de inclusão social das pessoas com deficiência nos mais altos níveis de competitividade do fenômeno esportivo na contemporaneidade. 
Todavia, conforme afirmam Gonçalves, Albino e Vaz (2009), a recorrente correlação do esporte paraolímpico com o olímpico por parte da mídia parece ser uma condição de existência do primeiro no interior do universo midiático-esportivo. Para Marques (2016), este tipo de correlação pode secundarizar a esportividade do atleta paraolímpico e/ou com deficiência. Compreendidas dessa maneira, as figuras 7 e 8 podem sugerir que os sentidos de inspiração e legitimidade do esporte para pessoas com deficiência podem estar à mercê de elementos sociais simbólicos que não necessariamente representam a manifestação esportiva paraolímpica ou que estão condicionadas ao seu correlato olímpico. Por outro lado, a composição sígnica e o enquadramento ali representado pode também indicar um processo de convívio de atletas com deficiência e sem deficiência no mesmo espaço no âmbito esportivo. Este tipo de enquadramento pode, portanto, ser percebido como uma perspectiva imagética que reconhece e valoriza aspectos técnicos e físicos da esportividade dos atletas representados, independentemente de eles terem - ou não - deficiências.

\section{A melancolia da deficiência}

Enquanto as imagens que se encaixam na categoria anterior demonstram a força, o vigor, a esportividade e a combatividade dos atletas, nesta categoria as fotos associam a deficiência a sentimentos de sofrimento, dor e fragilidade. Imagens deste tipo são comuns na cobertura do esporte paraolímpico (PAPPOUS et al., 2009). A cobertura midiática tende a reproduzir o que Hilgemberg (2014) chama de "paradigma do coitadinho". O atleta paraolímpico é apresentado como vítima da deficiência, o que por sua vez acaba por complementar "o processo de objetificação da pessoa com deficiência", em que "estes indivíduos se tornam a personificação de suas deficiências" (HILGEMBERG, 2014, p. 54-55). Em suma, este modelo ocorre quando a mídia enfoca apenas a deficiência do atleta - ao invés de retratá-lo como um ser humano - objetificando-o como se o mesmo não fosse nada mais do que a sua própria deficiência.

As fotografias não necessariamente posicionam os atletas como vítimas das suas deficiências. No entanto, algumas das suas características - retratos com pouca iluminação e/ou sombras, por exemplo - denotam um sentimento de tristeza e/ou sofrimento. As figuras 9 e 10 são exemplos disto e podem conduzir o leitor a associar o universo da pessoa com deficiência com uma existência sombria/obscura. 


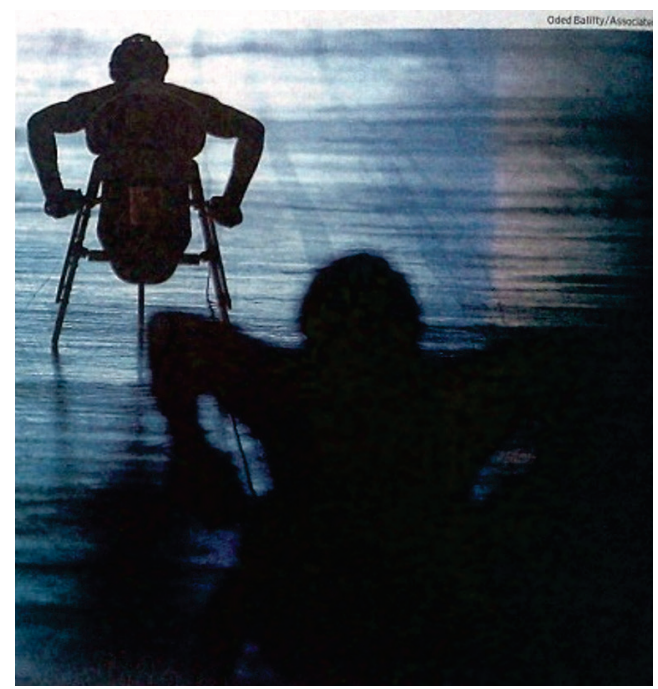

Figura 9: FSP (04/09/2008)

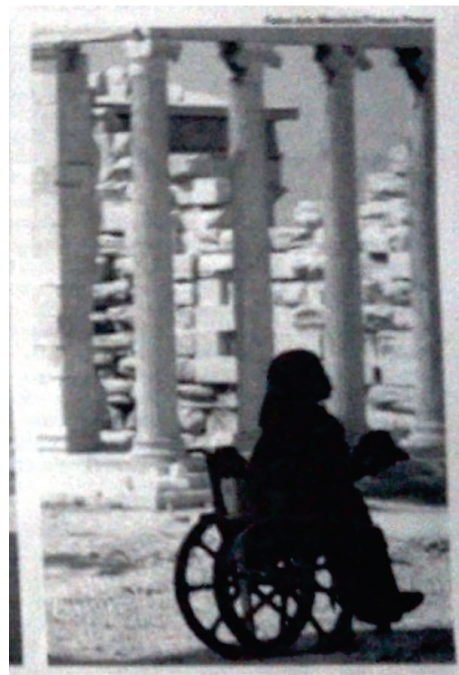

Figura 10: FSP (16/09/2004)

As figuras 11 e 12 também se encaixam nesta categoria, pois mostram os desportistas sozinhos e passam a impressão de que o atleta com deficiência é isolado do convívio social.

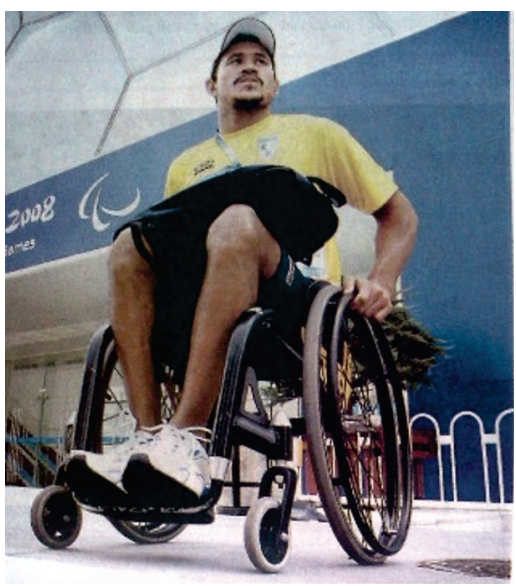

Figura 11: FSP (05/09/2008)

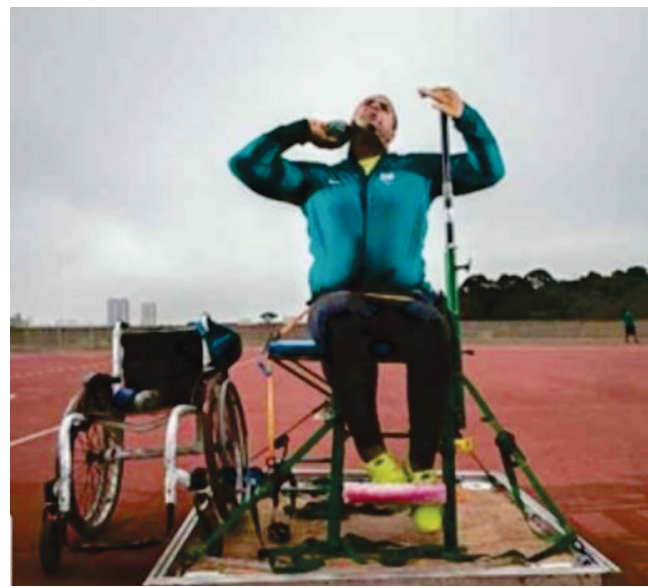

Figura 12: FSP (06/09/2016)

No universo do esporte, existem momentos em que os atletas precisam ficar a sós para se concentrar e se preparar para as provas. Porém, a repetição de imagens como estas podem reforçar o estigma de que as pessoas com deficiência são solitárias e isoladas, o que por sua vez, contribui para com o fortalecimento de uma identidade virtual deturpada 
deste grupo de pessoas. Ou seja, elas ajudam a solidificar o que Goffman (2012) chamaria de identidade deteriorada das mesmas.

A melancolia também foi perceptível em imagens que retrataram os atletas no pódio, local que normalmente é de alegria e celebração. A FSP publicou algumas fotos em que os atletas aparecem com expressão de sofrimento (ex. figura 13) e/ou com sorriso pouco expressivo (ex. figura 14) naquele que pode ser considerado o momento máximo de êxito do contexto esportivo, a premiação dos medalhistas.
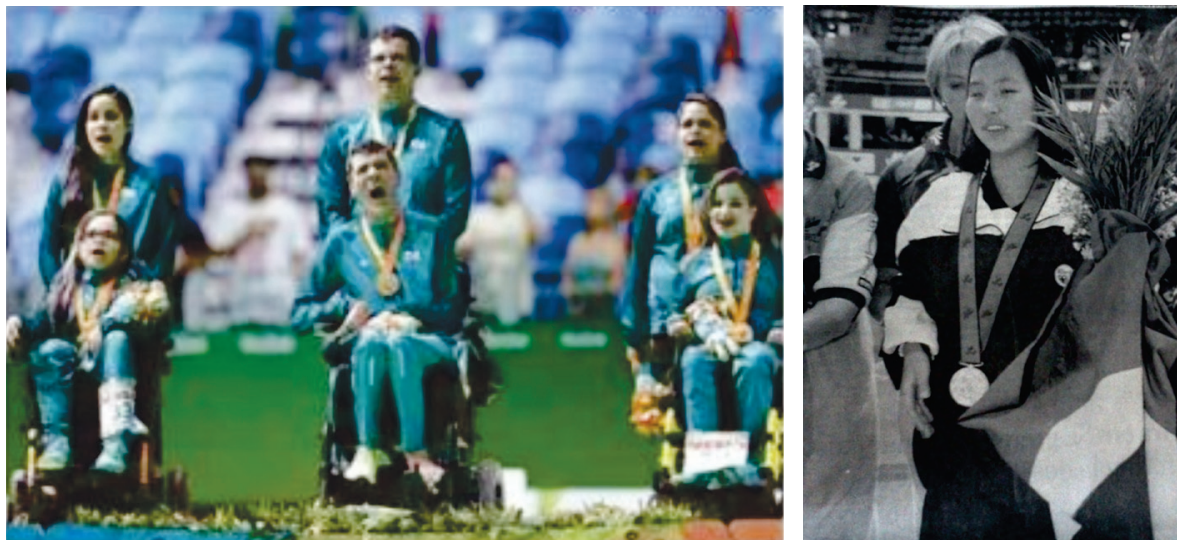

Figura 13: FSP (19/09/2016)

Figura 14: FSP (29/10/2000)

Várias imagens também mostram momentos de dor ou sofrimento durante as provas da competição. Exemplos disto são as imagens abaixo. A figura 15 retrata o atleta deitado, exausto, ao término de uma prova de atletismo. A figura 16 mostra um enquadramento do rosto do paraciclista italiano Alessandro Zanardi também com expressão de dor e sofrimento. Do ponto de vista do enquadramento fotográfico, se a FSP quisesse apresentar a virilidade, a força, a potência e o desempenho esportivo dos atletas, teria selecionado imagens destes correndo, no caso da primeira figura, e pedalando, no caso da segunda.

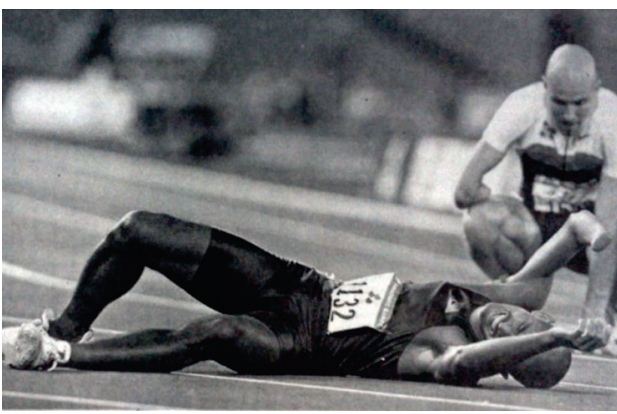

Figura 15: FSP (23/10/2000)

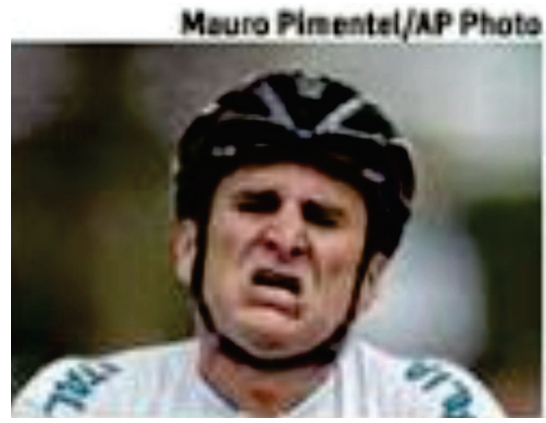

Figura 16: FSP (19/09/2016) 
A emoção da vitória e/ou derrota, retratada no momento do pódio ou na ultrapassagem da linha de chegada, assim como a dor e o sofrimento do esforço físico despendido por atletas de alto rendimento, são elementos inerentes à linguagem do esporte. Estes são componentes verbais e não verbais da linguagem utilizada na veiculação do discurso midiático-esportivo no esporte de uma forma geral (PIRES, 1998; BETTI, 2001). Todavia, ao mesmo tempo em que estas imagens ajudam a caracterizar a dimensão humana da manifestação esportiva, seja olímpico ou paraolímpico, elas podem também reforçar uma dimensão melancólica estereotípica que tende a circundar o universo das pessoas com deficiência.

\section{O nacionalismo}

Um dos indícios imagéticos encontrados nesta categoria relaciona-se com personalidades que, por serem amplamente conhecidas e reconhecidas pelos seus feitos, tendem a ser percebidas como representantes da nação. Um exemplo que se encaixa nesta categoria é uma imagem de Pelé, ex-jogador de futebol, mundialmente conhecido, e que carrega o título de "Rei" devido aos seus feitos esportivos ao longo da sua carreira (Figura 17).

Vale destacar que durante os JP de 1996, quando a foto do Pelé foi publicada junto a atletas paraolímpicos, a representação simbólica de nacionalidade que ele possuía não era apenas pela sua trajetória futebolística. Naquele momento ele era também ministro extraordinário do esporte no Brasil, cargo que ocupou de 1995 a 1998 durante o governo do presidente Fernando Henrique Cardoso. No que tange o enquadramento fotográfico da cobertura dos JP de 1996, temos o ex-atleta cumprimentando uma pessoa com deficiência, sendo ele (Pelé) um elemento sígnico de representação nacionalista mundialmente conhecido. Poderíamos elencar, também, que a partir de uma análise semiótica, sua imagem está relacionada a um representante esportista, (talvez) um exemplo a ser seguido, como também, podemos destacar que o esporte e o atleta paraolímpico estão à margem de um signo midiático-esportivo sem nenhuma vinculação direta com a referida manifestação esportiva. Dito isto, destacamos a presença de outra personalidade, o atleta Daniel Dias (Figura 18) que aparece dezoito vezes na cobertura da FSP nas publicações analisadas, sendo quatro vezes nos JP de Pequim 2008, oito vezes nos JP de Londres 2012 e seis vezes nos JP do Rio 2016. É perceptível que houve um declínio de imagens retratando o atleta nos JP/2016, porém, vale lembrar que neste ano houve oitenta e três imagens publicadas e, nos anos anteriores, dezenove imagens em 2012 e vinte e quatro imagens em 2008 ao longo dos eventos. Também cabe ressaltar que nos jogos de Londres se tinha muita expectativa sobre o nadador, considerando que, em 2011, o mesmo foi reconhecido como o maior atleta do esporte paraolímpico brasileiro por ter conquistado onze medalhas de ouro nos Jogos ParaPan-Americanos de Guadalajara-México. Em contrapartida, nos jogos do Rio, o atleta conquistou nove medalhas - quatro de ouro, três de prata e duas de bronze -, sendo o maior número dele depois dos jogos no México ${ }^{8}$.

8 Mais informações no link: http://danieldias.esp.br/. 
Ao longo da análise de dados encontramos diferentes imagens que ao invés de fazer um enquadramento do atleta em seu "espaço de trabalho", com uniforme, com um semblante "inspirador", como a figura 18, percebemos imagens em que o foco é puramente na deficiência, no estranho ${ }^{9}$. Nesse sentido, destacamos que a imagem do nadador está marcada pela sua representatividade nacional em relação ao esporte para pessoas com deficiência, como também, que o modo como foi apresentado destaca a modalidade que pratica sem enfatizar na deficiência. Trouxemos para o debate sobre o nacionalismo a relação entre Pelé e Daniel Dias, por entendermos que o esporte para pessoas com deficiência foi sendo construído na sombra do fenômeno esportivo para pessoas sem deficiência por muito tempo. Antes de Daniel Silva, o esporte paraolímpico obteve como representante o nadador Clodoaldo Silva, mas por pouco tempo. Pois, especificamente no caso dos nadadores seus feitos esportivos eram sempre comparados a atletas como por exemplo, Michel Phelps, nadador norte americano.

De acordo com Bruce (2014), a mídia tende a identificar os atletas com a sua nacionalidade, reproduzindo um senso de nacionalismo. Quando isto acontece, "a identidade nacional se torna o principal marcador de identidade, a cobertura da mídia aumenta em quantidade e se expande em complexidade, especialmente para atletas cujos sucessos permitem que o país se sinta bem consigo mesmo" (BRUCE, 2014, p. 1447). Nestes casos, a deficiência do atleta tende a não aparecer ou a não ser enfatizada.

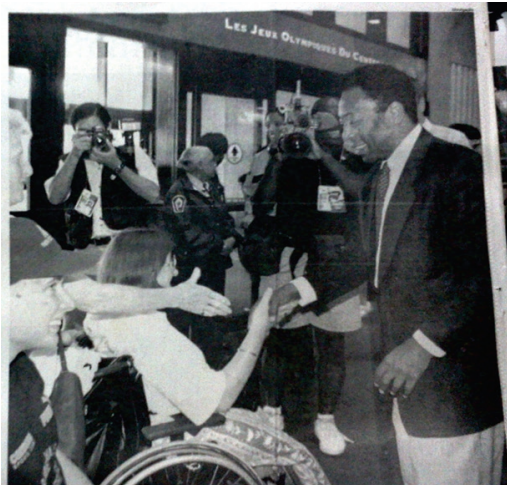

Figura 17: FSP(15/08/1996)

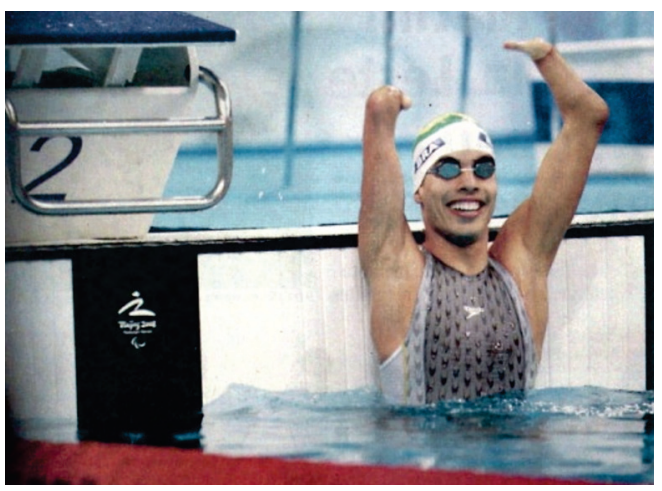

Figura 18: FSP(16/09/2008)

Outro ponto que destacamos refere-se aos momentos de abertura e encerramento dos JP, pois, a celebração dos rituais esportivos faz parte da ideia de um progresso infinito da modernidade, no qual estes eventos constituem-se como importantes mecanismos de fortalecimento das identidades (BITTENCOURT et al. 2005). Estas cerimônias oportunizam que todas as nações sejam reconhecidas através de seus atletas e que o sentimento de pertencimento seja enaltecido ao longo do evento.

9 Esta discussão será aprofundada no tópico posterior. 


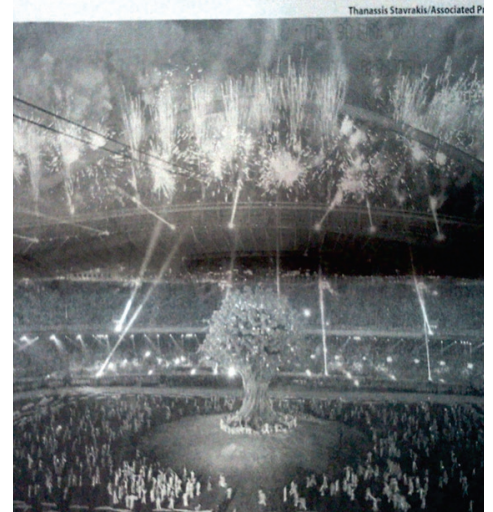

Figura 19: FSP (18/09/2004)

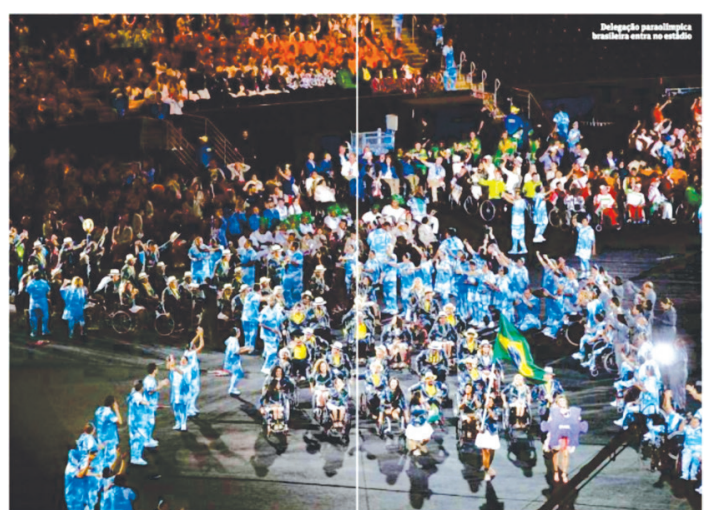

Figura 20: FSP (08/09/2016)

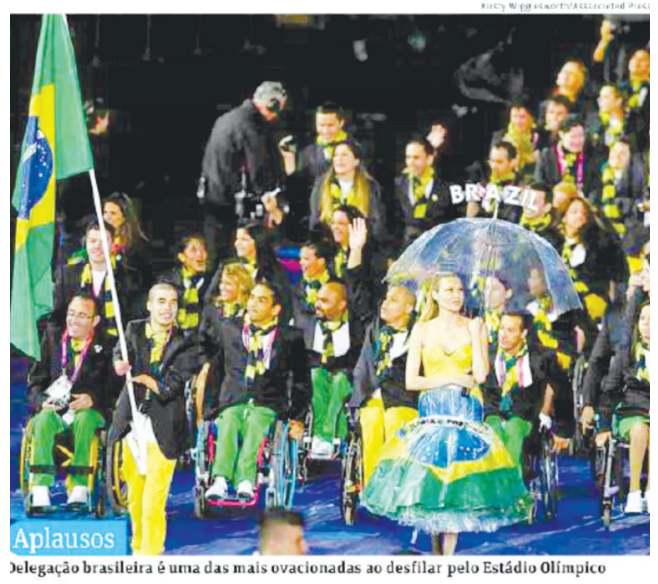

Figura 21: FSP (30/08/2012)

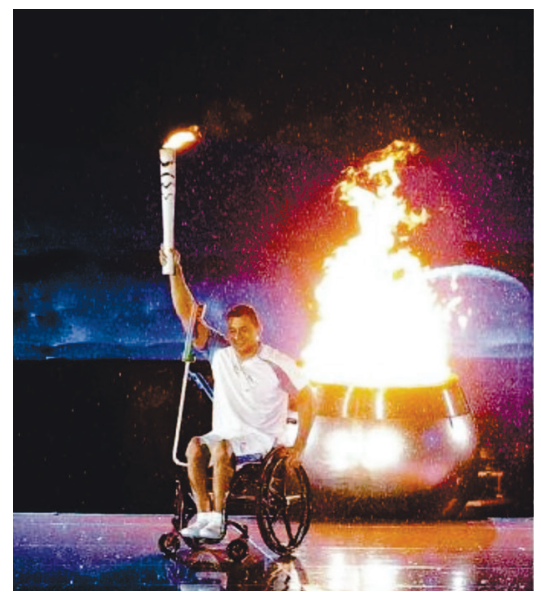

Figura 22: FSP (08/09/2016)

As fotografias acima se alinham com a ideia de que "[...] este rito [das aberturas e encerramentos] é marcado pela expectativa da quebra de recordes, de força, velocidade e altura, e aposta em todas as possibilidades para que estes objetivos sejam alcançados" (BITTENCOURT et al., 2005, p. 28). Os JP, como um todo, fazem parte de um ritual de celebração que envolve superação de obstáculos, evoca a alteridade como meio de se demarcar identidades, e enfatiza valores morais e éticos, elementos fundamentais para a construção da identidade das nações. Portanto, os enquadramentos fotográficos e os signos de nacionalidade presentes nas imagens dos rituais, além de registrarem a celebração de início e fim das edições dos JP, apresentam indícios semióticos que elucidam sentimentos e identidades nacionalistas, ainda que seja uma vinculação sígnica generalista em relação ao esporte paraolímpico. 
Ressaltamos também algumas imagens que se destacam pelos símbolos e/ou cores que identificam o Brasil. No caso da figura 23, embora esta não apresente as cores do país, uma vez que a foto foi publicada em preto e branco, a imagem mostra a atleta de braços abertos, segurando a bandeira nacional. Já as figuras 24, 25 e 26 mostram as cores da bandeira, e no caso das duas últimas, o nome do país. O discurso imagético destas fotos propaga um sentimento de nacionalismo e aproxima os brasileiros dos atletas, por estarem representando o país. Estes ícones de representação da brasilidade propiciam que o torcedor se sinta parte dos feitos esportivos e vitórias dos atletas.

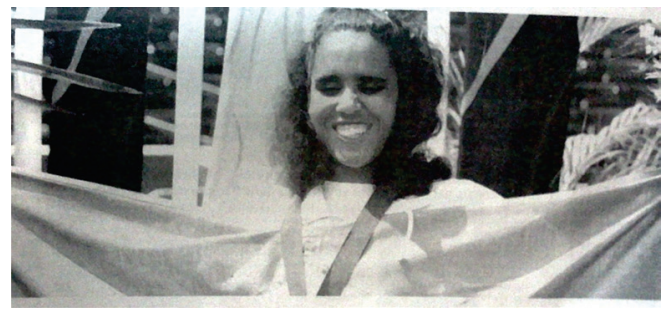

Figura 23: FSP (23/08/1996)

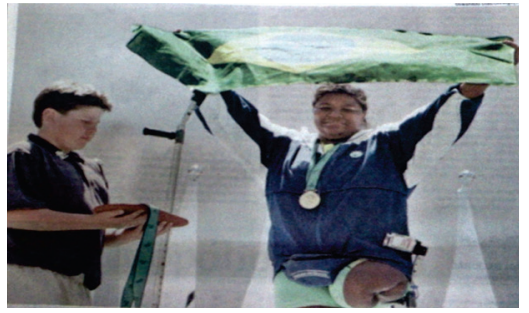

Figura 24: FSP (24/10/2000)

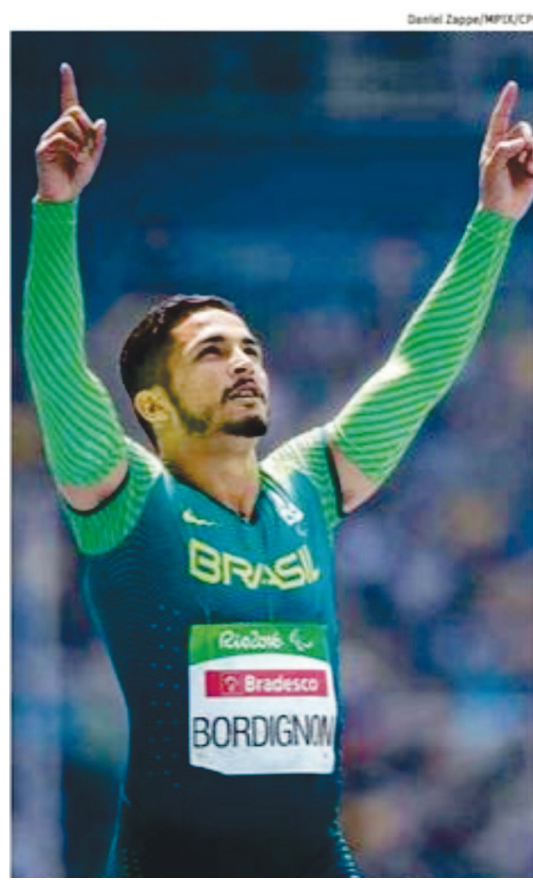

Figura 25: FSP (13/09/2016)

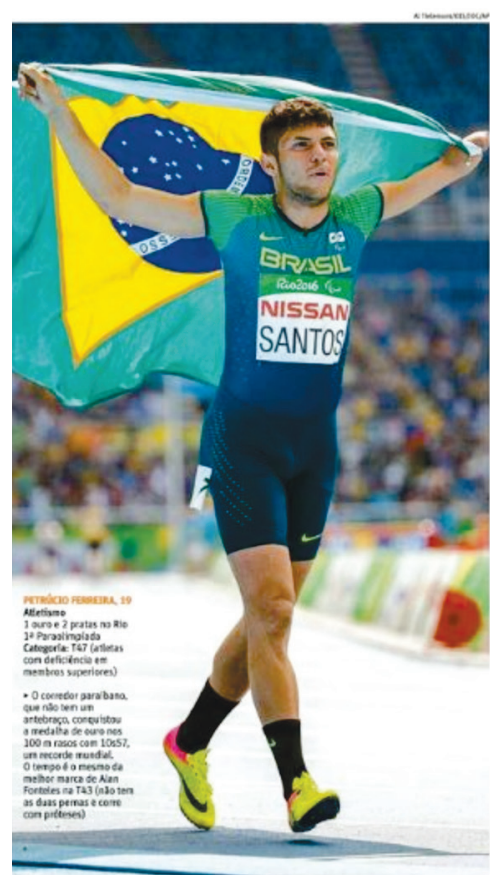

Figura 26: FSP (19/09/2016) 
Para finalizar, ressaltamos que no caso da última edição analisada - os JP 2016 -, signos que representam o Brasil, como por exemplo as cores da bandeira, apareceram em $47,92 \%$ das imagens, sendo que, nos anos anteriores, não apareceu mais do que nos $16,67 \%$ registrados nas fotos em 2008. Podemos afirmar que este crescente das imagens nacionalistas associadas ao esporte paraolímpico na cobertura da FSP está relacionado com o fato de os Jogos terem ocorrido no Brasil. Além disto, foi a primeira vez que a equipe paraolímpica brasileira participou de todas as modalidades esportivas (22) e que teve um número tão expressivo de atletas (286).

\section{Espetacularização do grotesco ao ciborgue}

As fotografias aqui categorizadas enfatizam o corpo deficiente, estranho/diferente e não raramente ligado à novas tecnologias. Conforme apontam Zoboli, Correa, Lamar (2016, p. 660), "a incorporação de tecnologias presente no meio esportivo vem cada vez mais recebendo importância no desenvolvimento dos atletas que visam a um avanço técnico ou físico para melhorar suas performances rumo à superação de limites e quebra de recordes". No que tange ao campo do grotesco, apresentamos como exemplo imagens que retratam o atleta fora e dentro de seu campo de atuação (natação, atletismo, jogos coletivos, entre outros), mostrando o corpo dos mesmos a partir do que se estranha, ou que foge do que Coakley (2009) chamaria de "império da normalidade".

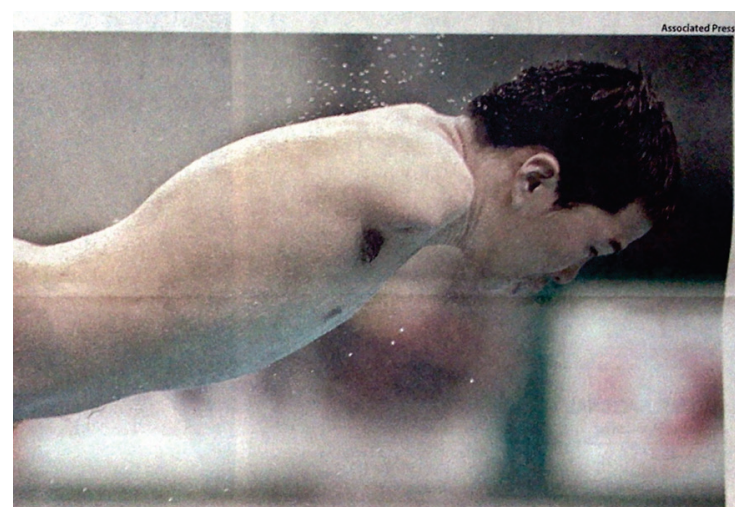

Figura 27: FSP (17/10/2000)

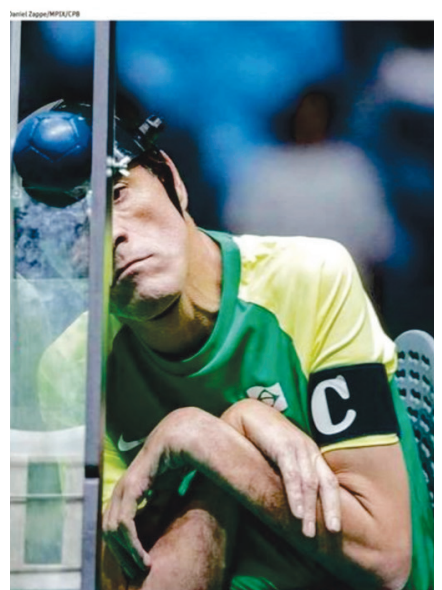

Figura 28: FSP (13/09/2016) 


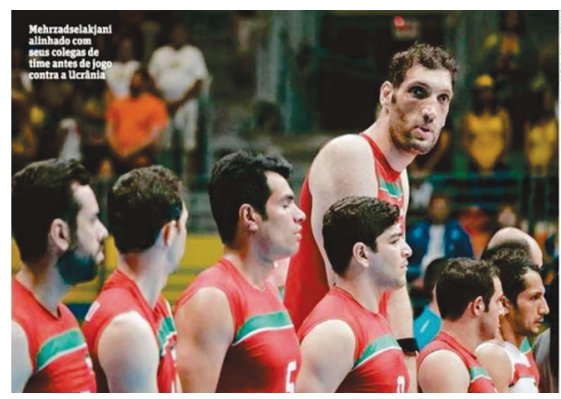

Figura 29: FSP (16/09/2016)

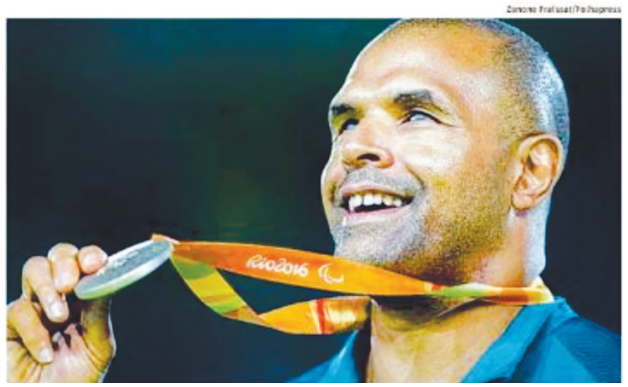

Figura 30: FSP (11/09/2016)

Fotos tais como as demonstradas acima chamam a atenção para a estética do corpo. Conforme diriam Pappous et al. (2009, p. 36), "la atención del lector se centra en la discapacidad gracias a los elementos auxiliares, la colocación del punto deficiente en el centro, la composición y el carácter flou del fondo". Ao explorar a veiculação de fotografias como estas na sua cobertura, com enquadramentos fotográficos fechados nos braços amputados do nadador (Figura 27), na distrofia muscular do jogador de bocha (Figura 28), no gigantismo do jogador de vôlei sentado (Figura 29) e nos olhos cegos do judoca (Figura 30), a FSP estaria corroborando para a construção de uma semiosfera que prioriza o "espetáculo da deficiência", verdadeiros "freak shows", em detrimento de um protagonismo no espetáculo esportivo.

Conforme se pode observar na tabela 1, ao longo dos anos, pode-se também notar uma disposição da FSP em evidenciar registros de diferentes tecnologias utilizadas pelos atletas para auxiliar na performance esportiva, fato este que teve um aumento significativo na última edição dos Jogos com vinte e quatro imagens $(55,81 \%)$. Estes registros realçam corpos híbridos que, de acordo com Zoboli et al. (2014, p. 166), "são corpos virtualizados via informática, corpos reconstruídos por meio de próteses biônicas de última geração, corpos modificados geneticamente, em suma, corpos híbridos". Maika e Kanylchuck (2016) que também realizaram um estudo para analisar o enquadramento jornalístico dos Jogos Paralímpicos por parte de dois jornais canadense ${ }^{10}$ também apontaram a mesma tendência de enfatizar corpos tecnologizados, a qual eles denominaram de "cyborg framing". Algumas das fotos publicadas pela FSP permitem novas formas de concebermos e configurarmos o corpo, o esporte e a tecnologia. 


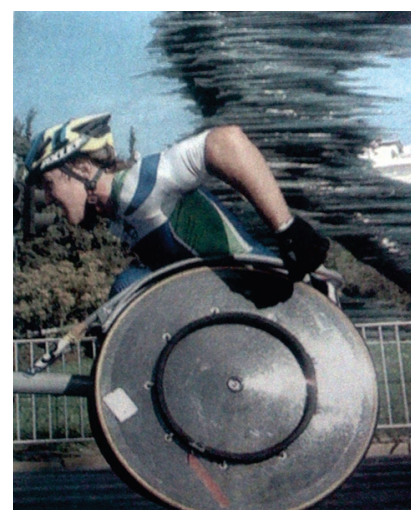

Figura 31: FSP (27/09/2004)

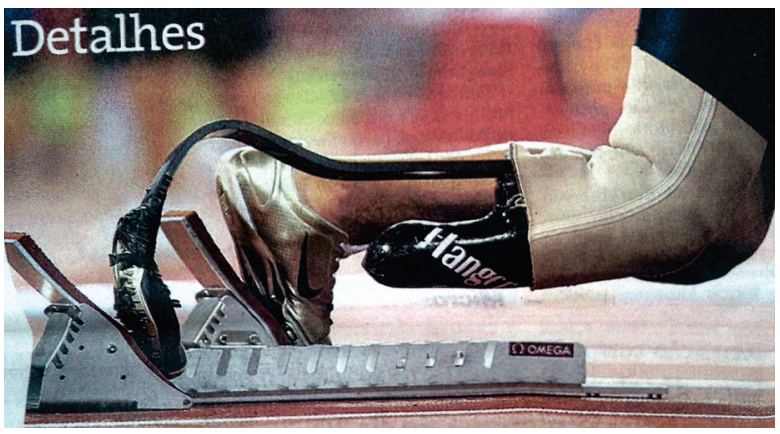

Figura 32: FSP (12/09/2008)

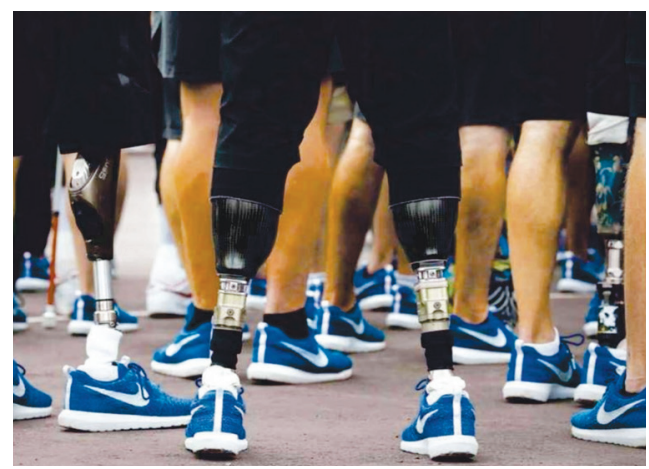

Figura 33: FSP (07/09/2016)

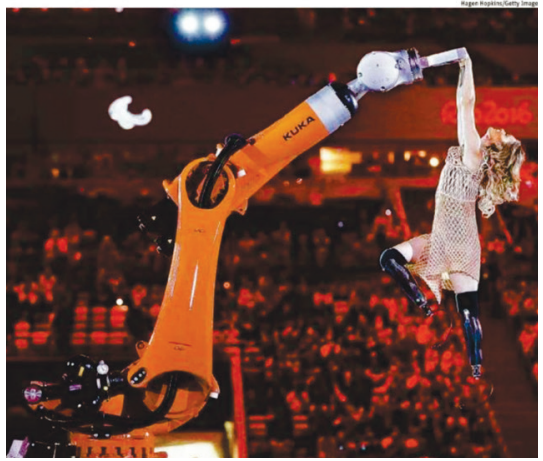

Figura 34: FSP (08/09/2016)

Podemos considerar o caso do esporte paraolímpico, conforme fotografado e veiculado pela FSP, como um fenômeno que transita entre o grotesco midiático-esportivo e o fetichismo tecnológico promovido pela representação icônica das próteses e cadeiras, as quais representam um novo momento social e econômico do universo das pessoas com deficiência. Cabe lembrar que, ao longo da história da humanidade, o olhar sobre o corpo deficiente sempre esteve voltado ao desprezo, à eliminação, ao preconceito, entre outras características que tinham como objetivo o afastamento das pessoas com deficiência do meio social. No passado, e em alguns casos ainda hoje, associa-se a imagem de pessoas com deficiência a "monstros" e "fracasso da criação". Na contemporaneidade, a evolução da tecnologia assistiva proporcionou às pessoas com algum grau de deficiência um melhoramento no desempenho das atividades do dia a dia e também nas atividades esportivas. "Nesse sentido, os aparatos tecnológicos não só vêm transformando o nosso cotidiano, mas, também, a nós mesmos naquilo que talvez (ainda?) tenhamos de mais "natural": nosso corpo" (ZOBOLI, CORREIA e LAMAR, 2016, p. 660). 
A categoria "espetacularização do grotesco ao ciborgue" representa uma característica da composição semiótica da cobertura dos JP na FSP, que ora coloca no centro do enquadramento fotográfico a deficiência dos atletas, e ora traz ao mesmo centro a simbiose corpo-tecnologia. Esta é uma narrativa imagética do esporte paraolímpico que, ao enfocar no estranhamento da primeira e no fetiche gerado pela segunda, apresenta indícios desta ser uma manifestação esportiva que ao ser midiatizada e espetacularizada é atravessada pelo principal elemento sígnico do contexto cultural das pessoas com deficiências: o corpo deficiente. Afinal, como afirmam Buysse e Borcherding (2010), a deficiência é parte importante da composição da identidade corporal dos atletas paraolímpicos. No entanto, quando o foco é exclusivo na deficiência e/ou no corpo híbrido, pode gerar uma identificação e objetificação do ser humano em pauta com a sua deficiência e/ou com a tecnologia que utiliza para minimizar as suas limitações.

\section{CONSIDERAÇÕES FINAIS}

A cobertura fotográfica da FSP sobre os JP de 1992 a 2016 apresentou algumas características recorrentes e compatíveis com o que vem sendo discutido na literatura: esportividade, melancolia, nacionalismo e espetacularização do grotesco e do ciborgue. O aumento de imagens veiculadas pela referida mídia ao longo dos anos acerca dos JP representa uma crescente valorização midiática desta manifestação esportiva. Imagens que mostram a esportividade do atleta, bem como os acessórios utilizados pelos mesmos (ex. cadeira de rodas, próteses, muletas, etc.), podem contribuir para com o processo de desestigmatização das pessoas com deficiência.

O caráter polissêmico identificado nas fotografias, no entanto, revela a complexidade do universo imagético, a dimensão inconclusa das representações sociais sobre o atleta com deficiência, e, por conta disso, reafirma os cuidados a serem tomados na aproximação, na relação e nas assertivas a serem desenvolvidas em relação ao mesmo.

Sabemos que as escolhas das imagens publicadas pela FSP fazem parte de um enquadramento editorial, ou seja, elas partem de um processo de seleção, exclusão e ênfase do que poderia ser e do que foi publicado. Estas escolhas, portanto, precisam ser cuidadosamente realizadas para que, na medida do possível, possam contribuir para com a construção de um imaginário social mais positivo em relação às habilidades e potencialidades das pessoas com deficiência.

Uma das limitações deste estudo refere-se à nossa opção de analisarmos apenas as fotografias, independentemente dos textos que as acompanhavam. Isto restringiu a nossa compreensão de questões que poderiam contextualizar os conteúdos expressos e não expressos das imagens. Optamos, no entanto, por correr o risco de trabalhar apenas com as fotografias, pois queríamos compreender o discurso das imagens por si próprias. Ou seja, queríamos compreender as mensagens não verbais produzidas pela FSP sobre o esporte e os atletas paraolímpicos. Fazem-se interessantes outros estudos que incorporem análises tanto do discurso verbal quanto do não verbal para ver até que ponto eles se 
complementam e/ou se contrapõem. Sugerimos também outras pesquisas que analisem imagens relacionadas com o esporte paraolímpico junto a outros meios de comunicação (redes sociais, televisão e portais digitais), bem como pesquisas junto a consumidores do esporte paraolímpico, no sentido de aprofundar a compreensão de quais - e como - símbolos e valores diversos da veiculação midiática estão sendo produzidos e incorporados no plano da cultura contemporânea.

\section{REFERÊNCIAS}

BETTI, Mauro. Esporte na mídia ou esporte da mídia? Motrivivência, Florianópolis, n. 17, p.1-3, 2001. Disponível em: < https://periodicos.ufsc.br/index.php/motrivivencia/ article/view/5929 > . Acesso em: 20 mar. 2017.

BITTERCOURT, Fernando Gonçalves et al. Ritual olímpico e os mitos da modernidade: implicações midiáticas na dialética universal/local. Pensar A Prática, Goiânia, v. 8, n. 1, p.21-36, 2005. Disponível em: < https://www.revistas.ufg.br/fef/article/ view/16061/9849>. Acesso em: 14 abr. 2017.

BRITTAIN, Ian; BEACOM, Aaron. Leveraging the London 2012 Paralympic Games. Journal Of Sport And Social Issues, [s.I.], v. 40, n. 6, p.499-521, ago. 2016. SAGE Publications. http://dx.doi.org/10.1177/0193723516655580.

BRITISH PARALYMPIC ASSOCIATION. Guide to Reporting on Paralympic Sport. 2012. Disponível em: < http://paralympics.org.uk/uploads/documents/imported/ ParalympicsGB_Guide_to_Reporting_on_Paralympic_Sport_-_June_2012.pdf > . Acesso em: 12 maio 2017.

BRUCE, Toni. Us and them: the influence of discourses of nationalism on media coverage of the Paralympics. Disability \& Society, [s.I.], v. 29, n. 9, p.1443-1459, 22 ago. 2014. Informa UK Limited. http://dx.doi.org/10.1080/09687599.2013.816624.

BUYSSE, Jo Ann; BORCHERDING, Bria. Framing Gender and Disability: A Cross-Cultural Analysis of Photographs from the 2008 Paralympic Games. International Journal Of Sport Communication, [s.l.], v. 3, n. 3, p.308-321, set. 2010. Human Kinetics. http://dx.doi.org/10.1123/ijsc.3.3.308.

COAKLEY, Jay. Age and Ability: Barriers to participation and inclusion? In: COAKLEY, Jay. Sports in Society: Issues and Controversies. 11. ed. New York: Mc Graw Hill Education, 2009. p. 302-349.

DEBORD, Guy. A sociedade do espetáculo. Rio de Janeiro: Contraponto, 1997. 240 p.

FIGUEIREDO, Tatiane Hilgemberg. Gênero e Deficiência: uma análise da cobertura fotográfica dos Jogos Paralímpicos de 2012. Estudos em Jornalismo e Mídia, [s.I.], v. 11, n. 2, p.484-497, 27 out. 2014. Universidade Federal de Santa Catarina (UFSC). http://dx.doi.org/10.5007/1984-6924.2014v11n2p484.

GOFFMAN, Erving. Estigma: notas sobre a manipulação da identidade deteriorada. 4. ed. Rio de Janeiro: LTC, 2012. 124 p. 
GONÇALVES, Gisele Carreirão; ALBINO, Beatriz Staimbach; VAZ, Alexandre Fernandez. O herói esportivo deficiente: aspectos do discurso em mídia impressa sobre o ParapanAmericano 2007. In: PIRES, Giovani de Lorenzi (org.). “Observando" o Pan Rio/2007 na mídia. Florianópolis: Tribo da Ilha, 2009. p. 149-167.

HARDIN, Marie Myers; HARDIN, Brent. The "Supercrip" in sport media: Wheelchair athletes discuss hegemony's disabled hero. Sosol: Sociology of Sport Online, Otago, v. 1, n. 7, p.1-14, 2004.

HILGEMBERG, Tatiane. Do Coitadinho ao Super-herói: Representação social dos atletas paralímpicos na mídia brasileira e portuguesa. Ciberlegenda, Niterói, n. 30, p.48-58, 2014.

HOWE, David. From Inside the Newsroom. International Review For The Sociology Of Sport, [s.l.], v. 43, n. 2, p.135-150, jun. 2008. SAGE Publications. http://dx.doi. org/10.1177/1012690208095376.

INTERNATIONAL PARALYMPIC COMMITTEE. Guide to reporting on persons with an impairment. 2014. Disponível em: < https:/www.paralympic.org/sites/default/ files/document/141027103527844_2014_10_31 + Guide + to + reporting + on + perso ns + with + an + impairment.pdf $>$. Acesso em: 12 abr. 2017.

MACHADO, Irene. Por que semiosfera? In: MACHADO, Irene. Semiótica da Cultura e Semiosfera. São Paulo: Annablume/fapesp, 2007. p. 15-23.

MAIKA, Melinda; DANYLCHUK, Karen. Representing Paralympians: The 'Other' Athletes in Canadian Print Media Coverage of London 2012. The International Journal Of The History Of Sport, [s.I.], v. 33, n. 4, p.401-417, 3 mar. 2016. Informa UK Limited. http://dx.doi.org/10.1080/09523367.2016.1160061.

MARQUES, Renato Francisco Rodrigues et al. A abordagem midiática sobre o esporte paralímpico: o ponto de vista de atletas brasileiros. Movimento, Porto Alegre, v. 20, n. 3, p.989-1015, 2014. Disponível em: < https://seer.ufrgs.br/Movimento/article/ view/41955/35210>. Acesso em: 15 abr. 2017.

MARQUES, Renato Francisco Rodrigues. A contribuição dos Jogos Paralímpicos para a promoção da inclusão social: o discurso midiático como um obstáculo. Revista USP, [s.I.], n. 108, p.87-96, 28 mar. 2016. Universidade de Sao Paulo Sistema Integrado de Bibliotecas - SIBiUSP. http://dx.doi.org/10.11606/issn.2316-9036. v0i108p87-96.

MARTÍN-BARBERO, Jesús. Ofício de cartógrafo: travessias latino-americanas da comunicação na cultura. São Paulo: Edições Loyola, 2004.

. Dos meios às mediações: comunicação, cultura e hegemonia. Rio de Janeiro: Editora UFRJ, 2009.

MENDONÇA, Ricardo Fabrino; SIMÕES, Paula Guimarães. Enquadramento: Diferentes operacionalizações analíticas de um conceito. Revista Brasileira de Ciências Sociais, São Paulo, v. 27, n. 79, p.187-235, 2012. 
PAPPOUS, Athanasios Sakis; SOUZA, Doralice Lange de. Guia para a mídia: Como cobrir os Jogos Paralímpicos Rio 2016. 2016. Disponível em: < https://static.kent.ac.uk/ media/news/2016/05/GUIA-paralimpicos.pdf>. Acesso em: 12 abr. 2017.

PAPPOUS, Athanasios Sakis et al. La representación mediática del deporte adaptado a la discapacidad en los medios de comunicación. Ágora Para La Ef y El Deporte, [s.I.], n. 9, p.31-42, 2009.

PAPPOUS, Athanasios (Sakis); MARCELLINI, Anne; LÉSÉLEUC, Eric de. From Sydney to Beijing: the evolution of the photographic coverage of Paralympic Games in five European countries. Sport In Society, [s.I.], v. 14, n. 3, p.345-354, abr. 2011. Informa UK Limited. http://dx.doi.org/10.1080/17430437.2011.557271.

PIRES, Giovani de Lorenzi. Breve introdução ao estudo dos processos de apropriação social do fenômeno esporte. Revista de Educação Física/UEM, Maringá, v. 9, n. 1, p.25-34, 1998.

ROTHBERG, Danilo. O conceito de enquadramento e sua contribuição à crítica de mídia. In: CHRISTOFOLETTI, Rogério. Vitrine e Vidraça: crítica da mídia e qualidade no jornalismo. Florianópolis: LabCom Books, 2010. p. 53-68.

SILVA, Carla Filomena; HOWE, David. The (In)validity of Supercrip Representation of Paralympian Athletes. Journal Of Sport And Social Issues, [s.I.], v. 36, n. 2, p.174194, 26 jan. 2012. SAGE Publications. http://dx.doi.org/10.1177/0193723511433865.

ZOBOLI, Fabio et al. Um olímpico paraolímpico: uma análise midiática da participação de Oscar Pistorius nas Olimpíadas de Londres 2012. In: MEZZAROBA, Cristiano et al. As olimpíadas e paraolimpíadas de 2012 na mídia sergipana. São Cristóvão: Editora UFS, 2014. p. 153-188.

ZOBOLI, Fabio; CORREIA, Elder Silva; LAMAR, Adolfo Ramos. Corpo, tecnologia e desporto: considerações a partir do caso da paratleta Danielle Bradshaw. Movimento (ESEFID/UFRGS), [s.I.], v. 22, n. 2, p.659-670, 29 jan. 2016. Universidade Federal do Rio Grande do Sul. http://dx.doi.org/10.22456/1982-8918.56441.

Recebido em: Outubro/2017

Aprovado em: Agosto/2018 